\title{
Review of Lisa Herzog's Inventing the market: Smith, Hegel, and political theory. Oxford University Press, 2013, 208 pp.
}

NORBERT WASZEK

University of Paris VIII (Vincennes à Saint-Denis)

This short but insightful book is based on the author's Oxford DPhil thesis. As its title indicates the book analyses and compares the constructions of the market by Adam Smith and G. W. F. Hegel, and puts special emphasis on their relevance for contemporary philosophical issues. Two challenges are central to this project. First, the obvious interdisciplinary angle of this study means that it takes its subject matter, the market, from the field of economics, but the treatment it receives "has little in common with economic theory as it is [generally] practised today" (p. 11). The intention of this study is rather to show how Smith's and Hegel's understanding of the market can benefit and deepen certain sterile (from the Hegelian point of view) contemporary philosophical debates such as the one on liberalism/ individualism versus communitarianism. Here Herzog's approach is certainly legitimate and deserves to be encouraged. Second, the author's sustained (and at times strained) efforts to make these historical thinkers "fruitful" for "contemporary problems" or at least current "debates" in political philosophy, lead her to advance a bold methodological programme which she calls "a post-Skinnerian approach" (pp. 11-14). The merits of Quentin Skinner and in general of the 'Cambridge school' of the history of ideas are not denied or minimized, but the author does argue that such "contextual" readings may lead to neglecting "systematic questions" (p. 12). This may be more contentious.

Chapter 1 provides a general introduction that highlights the meaning and, indeed, the power of the market over our lives, while insisting that the market "has not figured prominently in the political theory of the last decades [...] Often, the market seems to be the ghostly 'other' of the institutions political theorists focus on, something that needs to be tamed and restricted, but not itself made an issue" (p. 3). By way of this diagnosis (and the criticism it implies) the general direction of this study becomes evident. The introduction also provides 
some basic information on Smith and Hegel, as well as their impact on later thinkers (p. 5ff.), before arriving at the methodological statement already mentioned.

Chapters 2 and 3 give brief competent accounts of the respective "constructions of the market" by Smith and Hegel. On Smith, Herzog begins by attacking the superficial readings ("clichés") of The wealth of nations (WN) that were long common and survive in some economics textbooks and other odd corners. To deepen his image and to make Smith emerge more clearly as a philosopher, Herzog briefly describes his context and gives an idea of Smith's overall system-drawing not only upon $\mathrm{WN}$, but also The theory of moral sentiments, Lectures on Jurisprudence, and even his essay on the history of astronomy-and of his subtle notion of nature. The chapter culminates with Smith's account of the market society, presented in three steps: (a) the institutional framework with its classical tasks of protecting the members of society from foreign invasion as well as from internal oppression and of establishing an exact administration of justice; (b) the mechanisms and functions of the free market, including the metaphor of the "invisible hand"; (c) a consideration of the possible failures and insufficiencies of the market, and various remedies. The author might have paid more attention to the last point (dealt with in only about one page: 36-37), to counter-balance the optimistic conclusion of the preceding section on the general opulence that might spring from the proper functioning of the market it (she does however come back to this in chapter 6).

The chapter on Hegel begins with general overviews of Hegel's reception and the place that is (or is not, in more piece-meal revivals of certain aspects only of Hegel's practical philosophy) attributed to Hegel's system. While it is of course indispensable to sum up the relevant material I would have wished for a more decided stand on the issues, rather than playing the detached observer on points like this "some see [Hegel] as the forerunner of Marx and critical theory, others as a right-wing defender of the Prussian state [...] [who may have] paved the way to fascism" (p. 41).

The crucial section on the market begins with a summary of the historical evidence for Hegel's reading of Smith (and of political economy in general). Deciphering, and 'translating' as it were, the philosopher's difficult language into modern terms, Herzog finds the market economy in Hegel's "system of needs" and she succeeds in explaining it clearly-no slight achievement. She seems however to 
exaggerate the differences between Hegel and Smith, insisting that Hegel perceived the market as irrational-she uses not only the terms "unstable and unpredictable" (fair enough), but also refers to a "Dionysian, chaotic process" (p. 54f.). To be sure, Hegel underlined the undesirable and even dramatic impact that accidents, caprices, and faroff foreign circumstances may have on the market (was he not realistic and even far-sighted in this?) but, given the kind of philosopher he was, he could never be satisfied with the appearance of chaos. What strikes him at first glance as arbitrary, messy and even chaotic, always spurs him on to seek deeper understanding of the phenomenon under consideration. It is precisely for that reason that Hegel turns to the "new science" of political economy and even refers to its achievements as an "honour for thought"! What Herzog says of Smith, that "the task of science is to uncover the 'hidden chains' behind phenomena and to unite them into a coherent system" (p. 28), Hegel too would have accepted wholeheartedly. Indeed he says the same in his own words (Philosophy of right, § 189ff.).

The remaining four chapters address key issues in political philosophy for which Smith and Hegel can be seen as providing lasting inspiration. Chapter 4 "The self in the market" deals with the different and at times conflicting ways in which relations between the individual and society are seen both in recent political philosophy and by Smith and Hegel. Herzog is concerned to correct superficial readings according to which Smith, constructing "economic man" as an "atomistic" self, might be supposed totally opposed to Hegel, who as a devoted follower of Aristotle could hardly conceive an individual severed from the social whole. Reading Smith's economics more appropriately as coming from The theory of moral sentiments, with the strong emphasis given there to fellow-feeling and sympathy, Herzog insists that for Smith too, "men qua men cannot exist without society" (p. 63). In the wake of John Rawls's A theory of justice, this issue has sprung up again in Michael Sandel's criticism of Rawls for depending on an implausibly "unencumbered self" (Sandel 1984). Defenders of Rawls and Sandel have kept the controversy going, with some peacemakers (like Charles Taylor) trying to mediate. Herzog not only shows the significance of Smith and Hegel for this debate, she even renders their rich views on the social "embeddedness" of the self so attractive as to make the recent controversies seem old hat. 
Chapter 5 on "Justice in the market" is for me the heart of the book, especially the short but dense section "What about the poor?" (pp. 101111). Earlier within the same chapter, in a section on "Are market outcomes deserved?", Herzog returns to contemporary debates around Rawls's A theory of justice. When markets are seen as a consequence of just institutional structures, they may appear rationally "justified", but this falls short of any stronger sense of "just". Going further than Rawls, markets may also be evaluated in terms of whether their outcomes provide people with "what they deserve". As Herzog points out, for Hegel it would be wrong to ask such a question. Since the market or the "system of needs" is per se the realm of radical subjectivity, an expression of modern subjective freedom, arbitrariness and accident can never be banned from it. In this sense, I might add, ultra-liberal thinkers, like Hayek, may be described as following Hegel (pp. 86-89)though they might not like that idea; nor would many Hegelians have appreciated such a following! Along the same lines, Herzog is right in saying that "contemporary theory has largely followed a Hegelian strategy: it has given up the idea of realizing justice in markets, and has concentrated on the institutions that surround it" (p. 115), though contemporary thinkers may not always appreciate, or be aware of, the founding father of this strategy. It needs to be emphasized, however, for this does not emerge clearly enough from Herzog's presentation, that the "system of needs" is not Hegel's last or even sole word on the matter. The realm of egoism that Hegel associates with the market society is balanced by other parts of his system, coming before or after the relevant section in the Philosophy of right-and this separates Hegel definitively from the ultra-liberals. But rather than taking this aspect of the question further, let us proceed to the heart of the matter, the question of the poor.

Herzog continues her analysis by arguing that Smith was probably as preoccupied with the poor as Hegel-witness his many keen observations and comments on beggars, on charity, and so on. Herzog's point that the problem of poverty was a starting-point for Smith's thinking on economic matters may be strengthened by recalling the late Istvan Hont's brilliant analysis (1983) of the economic basis of the debates about Scotland's relation to England. But, as Herzog notes, in their theories about poverty there are also differences between Smith and Hegel. Under a condition that can neither be overestimated nor overstressed in presenting his views, Smith was convinced that a 
properly functioning, free market society may contribute to overcoming poverty, in the sense that it will help the poor to provide for themselves (see pp. 104-109). The condition sine qua non is economic growth; as Herzog expresses it, "the economic growth of commercial society is a tide that lifts all boats" (p. 103). What Smith thought might happen in the absence of constant growth is less clear, nor does he seem to be particularly worried about the costs that such growth might impose upon society (such as ecological problems) nor anticipate "alternative ways of securing economic prosperity" (p. 35).

Hegel, on the other hand, has a darker or, shall we say, more realistic view of poverty. The biblical aphorism, 'the poor will always be with us', never seems far from him. In more strictly economic terms, for Hegel poverty is a structural problem of market society, occurring just when "civil society" is in full swing (Philosophy of right, § 243). Hence the market cannot by itself provide a solution to the problem and "civil society is pushed beyond itself" ( $\S 246$ ). While Hegel may be and has often been accused of failing to provide a perfect solution to the problem of poverty, he does (pace Herzog, p. 110) provide a rather good discussion of possible remedies: the intervention of the public sphere, what he calls the "police", colonization, the corporations, and so on. Thus, this apparent weakness may dialectically be turned into a strength: Hegel is not trying to impose a dogmatic, ready-made answer that is bound to fail, but pragmatically exploring several ways out. However that may be, Herzog is good at reminding her readers of the brilliant things Hegel has to say about the non-material (in Hegel's terminology, 'ethical') dimensions and consequences of poverty (p. 107ff.).

The study ends with two related chapters, on the market's relation to freedom and the history of the market. The two topics are particularly related from the Hegelian point of view, for the philosopher gave the well-known definition of world history "as the progress of the consciousness of freedom". Chapter 6, on freedom and the market, begins with Isaiah Berlin's distinction between freedom from and freedom to, or between 'negative' and 'positive' liberty, and arrives at the conclusion that "these different notions of freedom should not be viewed as rivalling concepts", but rather as "a number of intrinsically related aspects or dimensions of freedom" (p. 15). While she documents a number of differences between Smith and Hegel, Herzog insists upon a fundamental agreement: "Smith and Hegel share the same idea: 
where the economic structures prevent the development of the citizen's capacity to act autonomously, the state has to take action" (p. 129). The study does touch upon such larger questions as the transition from the realm of the "objective" to that of "absolute spirit" in Hegel's system-for Hegel it is "clear that there are higher aims in life than pursuing commercial interests" (p. 131)—but such complex questions could have deserved a more detailed treatment. (Indeed several of the concluding chapters might have been developed at book length.) This is even more so in the brief concluding chapter on the market and history. Crucial issues are certainly raised, but it is utterly impossible to treat a difficult question like Hegel's "cunning of reason" satisfactorily in just one paragraph (see p. 152). A full consideration of Hegel's Lectures on the philosophy of world history would have been necessary for this.

\section{REFERENCES}

Hont, Istvan. 1983. The 'rich country-poor country' debate in Scottish classical political economy. In Wealth and virtue: the shaping of political economy in the Scottish enlightenment, eds. Istvan Hont, and Michael Ignatieff. Cambridge: Cambridge University Press, 271-315.

Sandel, Michael J. 1984. The procedural republic and the unencumbered self. Political Theory, 12 (1): 81-96.

Norbert Waszek, of German origin, concluded his formal education at Christ's College, Cambridge ( $\mathrm{PhD}$ 1984). Teaching and research appointments led him to Auckland (NZ), Hannover, Bochum ("HegelArchives"), and Erlangen in Germany, before settling in France, in 1992. He is now a senior professor ("classe exceptionnelle") of the history of ideas within the German studies department at the University of Paris VIII. His research focuses on German idealism, on the German, Scottish, and European enlightenment, and on German-Jewish thought. He is the author (or editor) of nineteen books and of 120 articles. Of particular relevance for the relation of economics and philosophy are his The Scottish enlightenment and Hegel's account of 'civil society' (Kluwer, 1988); Die Institutionalisierung der Nationalökonomie an deutschen Universitäten (Scripta Mercaturae, 1988); and L'Ecosse des Lumières: Hume, Smith, Ferguson (Presses Universitaires de France, 2003). More recently (2009 and 2011) he has co-edited two French editions of Hegel's lectures on the philosophy of history.

Website: <http://norbertwaszek.free.fr>

Contact e-mail: <norbert.waszek@gmail.com> 